\title{
THE BIG AND THE SMALL OF TAX SUPPORT FOR R\&D IN CANADA
}

\author{
Kenneth J. McKenzie ${ }^{\dagger}$ \\ The School of Public Policy and Department of Economics, \\ University of Calgary
}

\section{SUMMARY}

Innovation is critical in the knowledge-based economy. It is generally accepted that governments have an important role to play in promoting innovative activity and R\&D. Both the federal and provincial governments in Canada provide tax subsidies, and other forms of support, for R\&D. Changes to various programs offered by the federal government were introduced in Budget 2012, most particularly related to the Scientific Research and Experimental Development (SR\&ED) tax credit program. This paper analyzes the state of tax subsidies for R\&D both pre- and post-budget, and at both the federal and provincial level. It is shown that there is a patchwork of effective tax subsidy rates in Canada, which vary both between and within provinces, between small versus large firms, and across sectors and types of $R \& D$ activity. The result is a misallocation of $R \& D$ resources and a system of government support that is less effective than it could be. On some dimensions Budget 2012 was a move in the right direction, but on other dimensions matters were made worse, resulting in a reconfiguration of tax support across $R \& D$ activities that is more distortionary and less efficient. Most particularly, the post-budget tax system heavily favours small firms over large firms, and labour intensive R\&D over capital intensive R\&D. This paper offers a lucid examination of $R \& D$ tax support pre- and post-budget, and argues persuasively that Canadian governments should adopt a more uniform, less distortionary approach to tax subsidies for R\&D if they are truly interested in setting innovation free.

\footnotetext{
$\dagger$ The author wishes to acknowledge the helpful comments of the anonymous referees.
} 


\section{INTRODUCTION}

In its March 29, 2012 budget the federal government introduced several changes to the support provided to research and development $(R \& D)$ in Canada. These changes involved lowering the general federal tax credit rate for Scientific Research and Experimental Development (SR\&ED), and eliminating or reducing the credit for certain types of expenditures. Coupled with this reduction in indirect support for $R \& D$ delivered via the tax system, direct support for $R \& D$ via government grants was increased, additional funding was allocated for venture capital initiatives, and additional support was provided to research in universities and other research institutes. Moreover, government procurement practices are to be augmented to favour innovative suppliers.

While tax subsidies to R\&D in Canada remain high (as will become evident below), the budget marks a moderate shift away from indirect tax-delivered support for R\&D to direct support by way of government grants and spending. This shift is generally consistent with the recommendations of the Jenkins Report on federal support for R\&D issued in October of 2011. ${ }^{l}$

The purpose of this paper is primarily twofold. The first is to analyze the state of tax incentives provided for R\&D in Canada prior to the budget, and to discuss the impact of the changes announced in the 2012 federal budget. The second is to take a broader look at tax subsidies for $R \& D$ at both the federal and provincial level, with a view to assessing the efficiency of the overall system.

The emphasis in this paper is not so much on the overall level of support for $\mathrm{R} \& \mathrm{D}$, or on the shift from indirect to direct support, but rather on the structure and configuration of the tax support for R\&D, with particular attention paid to complementary provincial provisions.

A key aspect of the analysis is the calculation of effective tax (or rather subsidy) rates on $R \& D$ in Canada. These calculations are based on the concept of the marginal effective tax rate (METR) on capital. As discussed below, METR calculations provide a summary measure of the incentive effects of the tax system with respect to investment. Various METR calculations are presented for R\&D for the pre- and post-Budget 2012 systems, taking account of federal and provincial tax incentives provided for both Canadian Controlled Private Corporations (CCPCs, so-called small corporations) and non-CCPCs (large corporations).

The analysis shows that the changes introduced in the budget result in a significant reduction in the support for R\&D offered through the tax system, particularly for large corporations. This, of course, was precisely what was intended. Nonetheless, effective tax subsidy rates remain high and, as indicated above, the reduction in indirect support provided through the tax system is offset to some extent by an increase in direct support via government grants. However, and importantly, the analysis shows that the budget also significantly alters the configuration of relative effective subsidy rates across different types of $\mathrm{R} \& \mathrm{D}$ expenditures, between large and small firms, and therefore across sectors. It is argued that this reconfiguration is ill-advised and will lead to distortions and inefficiencies in the allocation of R\&D effort across activities. Most particularly, the post-budget tax system heavily favours small corporations over large firms, and labour-intensive R\&D over capital intensive $R \& D$ - even more so than the pre-budget regime - with no clear economic justification.

\footnotetext{
1 See Public Works and Government Services Canada (2011). Innovation Canada: A Call to Action, Review of Federal Support to Research and Development - Expert Panel Report, at http://rd-review.ca/eic/site/033 .nsf/vwapj/R-

D_InnovationCanada_Final-eng.pdf/\$FILE/R-D_InnovationCanada_Final-eng.pdf.
} 
It is also shown that METRs on R\&D vary widely across (and even within) provinces, due to special provincial programs and differences in income tax and tax credit rates across the provinces. As a result, there is a plethora of METRs on investment in R\&D across the country, with effective subsidy rates varying widely depending upon the size, location and nature of the $R \& D$ activities. The proliferation and variation in effective subsidy rates for $R \& D$ offered through the tax system is distortionary, inefficient and lowers the overall efficacy of government support for R\&D in Canada.

Reducing tax incentives for R\&D and shifting to more direct support may (or may not) be appropriate from a broad policy perspective. However, in terms of how this is done on the tax side, a better approach would be to lower tax subsidy rates in a less distortionary fashion, one that treats all types of R\&D inputs and large and small corporations in a more uniform, neutral manner.

\section{METRS AND THE NATURE OF R\&D}

The marginal effective tax rate (METR) on capital is a summary measure of the impact of the tax system on the incentive to undertake various types of capital investments. The methodology is typically applied to investments in physical, tangible capital. High METRs on capital suggest that the tax system discourages investment, and variations in METRs across different types of capital, sectors, and jurisdictions indicates the presence of inter-asset, inter-sectoral and interjurisdictional tax distortions, all of which impinge upon the efficient allocation of resources in the economy and lower economic output. The School of Public Policy at the University of Calgary has the largest METR model and database in the world, which now includes 90 countries. $^{2}$

At the risk of engaging in cliché, investment in intangible capital is thought to play an increasingly important role in the so-called knowledge economy. This suggests the need to measure tax incentives on intangible knowledge capital in an economically sensible manner, and in particular to adapt the METR approach to intangible capital.

Investment in intangible R\&D capital differs from investment in tangible, physical capital in several important ways. A key difference is that $R \& D$ activities are thought to be characterized by significant market failures.

Perhaps the most widely discussed market failure is the presence of externalities, or knowledge spillovers, which are thought to emanate from R\&D activity. Knowledge spillovers exist if the R\&D activity of one firm creates knowledge that is beneficial to other firms. As the firm accounts only for the private benefit of its $R \& D$, and not for the non-appropriable spillover benefits that accrue to others, this suggests that the social rate of return on an R\&D investment is greater than the private return to the firms that undertake it. As such, there is a tendency for private firms to underinvest in $R \& D$ and knowledge creation relative to the social optimum. This is the typical justification given for government-sponsored R\&D and for the provision of subsidies to encourage private sector R\&D.

2 See Chen, Duanjie and J. Mint (2011), Canada's 2010 Tax Competitiveness Ranking: Moving to the Average but Biased Against Services, SPP Research Paper Vol. 4, Issue 2, February 2011. The School of Public Policy, University of Calgary. 
However, there is another type of market failure associated with $R \& D$ which works in the other direction. It is called the business-stealing effect, and refers to the fact that firms seeking to discover and introduce an innovative product or process do not account for the negative impacts associated with the destruction of existing firms. The business-stealing effect suggests that potential innovators may overvalue their innovations and overinvest in $R \& D$. This effect suggests that governments should not subsidize R\&D but, on the contrary, should tax it.

There are other potential market failures associated with innovation and $R \& D$, but knowledge spillovers and the business-stealing effect are the most widely discussed and thought to be the most important. ${ }^{3}$ The problem, of course, is that they tend to work in opposite directions. A key issue from a policy perspective - in particular whether governments should tax or subsidize $\mathrm{R} \& \mathrm{D}-$ is which effect dominates.

The bulk of the empirical evidence suggests that the knowledge spillover effect dominates, and that the social rate of return to $R \& D$ is significantly higher than the private rate of return. For example, a widely cited but now somewhat dated study by Griliches, which summarized the state of the research at the time, concluded that "R\&D spillovers are present, their magnitude may be quite large, and social rates of return remain significantly above private rates." Little has changed over the last two decades; indeed, recent evidence suggests that spillovers may be even more important. For example, a recent paper by three economists well known for their research in the area - Nicholas Bloom, Mark Schankerman and John Van Reenan explicitly account for both types of market failures and shows that the knowledge spillover effect strongly dominates; on net, the social rate of return to R\&D is almost twice as high as the private rate of return. This order of magnitude is consistent with other studies. This means that private firms tend to underinvest in R\&D and that some form of government intervention to encourage $R \& D$, perhaps of the nature of subsidies for private investment, is justified. Interestingly, and importantly for the discussion that follows, Bloom, Schankerman and Van Reenan also find that knowledge spillovers emanating from small firms are significantly less than large firms. This issue will be returned to below.

Another important difference between tangible and intangible investments is the nature of the investments themselves. Investments in tangible capital typically involve buying a machine or a piece of equipment on the market, installing it and using it directly in the production process. Investment in $\mathrm{R} \& \mathrm{D}$, on the other hand, does not enter the production process directly. Rather, firms expend money on various types of R\&D activities, or inputs, with the objective of creating, or discovering, knowledge. This knowledge is an intangible asset that leads to new products or processes used in production. This suggests a two-stage process for investment in intangible R\&D capital, as opposed to a one-stage process for tangible capital. In the first stage

3 For a general discussion, and references to other studies, see Boadway, Robin and Jean-Francois Tremblay (2005), "Public Economics and Start-up Entrepreneurs," Venture Capital, Entrepreneurship and Public Policy, Kanniainen, V. and C. Keuschnigg, MIT Press, 181-219.

4 Griliches, Z. (1992), “The Search for R\&D Spillovers,” Scandinavian Journal of Economics Vol. 94, 29-47.

5 See Bloom, Nicholas, Mark Shankerman, John Van Reenan (2010), "Identifying Technology Spillovers and Product Market Rivalry," Stanford University, mimeo; Griffith, R. (2000), "How Important is Business R\&D for Economic Growth and Should the Government Subsidize It?," Institute for Fiscal Studies Briefing Note No. 12; Bernstein, Jeff (1988), "Costs of Production, Intra-and Interindustry R\&D Spillovers: Canadian Evidence," Canadian Journal of Economics 21(May): 324-347; (1989), "The Structure of Canadian Inter-Industry R\&D Spillovers and the Rates of Return to R\&D," Journal of Industrial Economics 37(March): 315-328; (1996), "International R\&D Spillovers between Industries in Canada and the United States, Social Rates of Return and Productivity Growth," Canadian Journal of Economics 29(April): S463-S467. 
the firm undertakes various expenditures on $R \& D$ inputs - scientists (labour), test tubes (materials), microscopes (capital), etc. These expenditures differ not only in their tax treatment, but also in their economic characteristics, some being of the nature of reoccurring current expenditures (labour, materials), others being of the nature of enduring capital expenditures (equipment). Expenditures on these $R \& D$ inputs then lead to the creation of an intangible asset which itself has enduring value - knowledge, or what I refer to as intangible R\&D capital which leads to new products or processes.

A methodology for calculating METRs on intangible R\&D capital, which explicitly takes account of these characteristics of $R \& D$, has been developed by McKenzie. ${ }^{6}$ Details of the approach are not provided here; rather, the methodology is applied to evaluate $\mathrm{R} \& \mathrm{D}$ tax incentives in a Canadian context along several dimensions. ${ }^{\text {? }}$

\section{METRS ON R\&D IN CANADA: RESULTS}

In this section the results of the METR analysis applied to R\&D are presented. Before discussing the results, it is useful to very briefly summarize the essential elements of the tax system as it relates to $\mathrm{R} \& \mathrm{D}$ in Canada. ${ }^{8}$

Prior to Budget 2012, under the SR\&ED program the federal government provided a 20 percent tax credit for R\&D expenditures for large (non-CCPC) corporations, and an enhanced 35 percent credit for small corporations (CCPC). Eligible R\&D expenditures include salaries and wages directly engaged in $R \& D$, the cost of materials consumed or transformed in $R \& D$, the cost (including leases) of machinery and equipment used in $R \& D$, expenditures incurred by contractors performing R\&D on behalf of the taxpayer, and overhead expenses. ${ }^{9}$ With respect to overhead expenses, firms had the option of itemizing overhead expenditures related to $R \& D$, or utilizing a proxy amount equal to 65 percent of expenditures on labour. In addition to the tax credit, all of these expenditure categories are expensed (written off immediately) for corporate income tax purposes.

6 McKenzie, K.J. (2005), "Tax Subsidies for R\&D in Canadian Provinces," Canadian Public Policy Vol. 31 No. 1, March, 29-44; (2008), "Measuring Tax Incentives for R\&D," International Tax and Public Finance Vol.15, 563-581.

7 The approach in McKenzie (2005, 2008 ibid) differs fundamentally from previous approaches to measuring METRs on R\&D. These approaches (see, for example, Griffith, R., D. Sandler and J. Van Reenen (1995), "Tax Incentives for R\&D," Fiscal Studies, Vol. 16, no. 2, 21-44; Gordon, K. and H. Tchilinguirian (1998), "Marginal Effective Tax Rates on Physical, Human and R\&D Capital," OECD Economics Department Working Paper 199; Mackie, J. (2002), "Unfinished Business of the 1986 Tax Reform: An Effective Tax Rate Analysis of Current Issues in the Taxation of Capital Income," National Tax Journal, Vol. 55, 293-337) are ad hoc in their treatment of R\&D capital, essentially treating the inputs into the creation of intangible R\&D capital as intangible R\&D capital in and of themselves. This ignores the underlying microeconomic foundations of the R\&D process, which involves aggregation based on the R\&D production function.

8 A nice summary of pre-budget R\&D tax incentives at both the federal and provincial level is KPMG (2011), Federal and Provincial Research and Development Tax Incentives, at

http://www.kpmg.com/Ca/en/IssuesAndInsights/ArticlesPublications/TaxRates/Federal\%20and\%20Provincial\%20Res earch\%20and\%20Development\%20Tax\%20Incentives.pdf

9 Overhead expenses are largely current expenses such as wages associated with support staff, supplies, the cost of utilities, etc. 
All of the provinces except PEI offer their own credits, for the most part piggybacking on the federal regime. The basic provincial credits range from 4.5 percent in Ontario; to 10 percent in B.C. and Alberta; 15 percent in Saskatchewan, New Brunswick, Nova Scotia and Newfoundland; 17.5 percent in Quebec; and 20 percent in Manitoba. ${ }^{10}$ For the most part provincial tax credits apply to the same expenditures as the federal base. An important exception is Quebec, which applies the credit to wages and contract R\&D expenditures only. Some provinces impose dollar limits on eligible expenditures and provide enhanced credits for certain types of expenditures. These are discussed below.

The 2012 budget lowered the basic federal tax credit applied to large corporations from 20 percent to 15 percent, eliminated the credit for non-current R\&D expenditures (i.e., for expenditures on capital equipment), restricted the credit to 80 percent of contract expenditures, and reduced the overhead proxy amount from 65 percent to 55 percent of R\&D labour expenditures. The enhanced federal tax credit for small corporations was left unchanged at 35 percent. These changes are to be fully implemented in 2014. As indicated previously, the reduction in tax subsidies will be offset to some extent by increases in direct spending on R\&D. As discussed by John Lester, ${ }^{11}$ these direct expenditures for the most part benefit small firms; on balance, when the changes are fully phased in, total R\&D support declines, while that for smaller firms increases slightly.

\section{Pre-Budget 2012}

\section{LARGE CORPORATIONS}

METR calculations for the pre-Budget 2012 tax system are provided for the 10 provinces and a weighted average total for Canada for large (non-CCPC) corporations in Table 1. It is worth noting that Ontario and Quebec dominate on the R\&D expenditure front in Canada, together accounting for over 80 percent of business R\&D expenditures. ${ }^{12}$ It should also be emphasized that these are combined METRs, reflecting both federal and provincial tax provisions related to $\mathrm{R} \& \mathrm{D}$ in each province. Also, the calculations in the table are for the standard provincial tax credit programs, presume that any R\&D expenditure limits are not binding and that enhanced credits that exist in some provinces for some types of expenditures do not apply. The implications of these limits and an analysis of some other provincial tax credits related to R\&D will be explored below. Finally, it is assumed that corporations are fully taxable and are able to claim all credits and deductions. ${ }^{13}$

\footnotetext{
10 Provincial credits lower the federal credit base, so effective provincial tax credit rates are lower. This is taken into account in the subsequent calculations.

11 Lester, John (2012), "Support for Business R\&D in Budget 2012: Two Steps Forward and One Back," mimeo

12 The weighted average total for Canada is determined by the provinces share of business R\&D expenditures, as reported by Stats Can. The shares are as follows: B.C. 7.4 percent, Alberta 7.0 percent, Saskatchewan 0.95 percent, Manitoba 1.3 percent, Ontario 51.2 percent, Quebec 30.6 percent, New Brunswick 0.62 percent, Nova Scotia 0.62 percent, PEI. 0.01 percent, and Newfoundland 0.25 percent (figures may not add up to 100 percent due to rounding).

13 The issue of tax loss firms is addressed later in the discussion.
} 
TABLE 1: R\&D METRS, LARGE CORPORATIONS, PRE-BUDGET 2012

\begin{tabular}{|c|c|c|c|c|c|c|c|c|c|c|c|}
\hline & 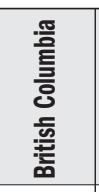 & 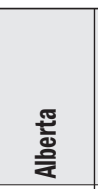 & 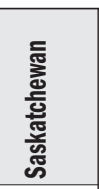 & 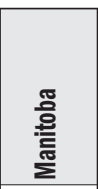 & $\begin{array}{l}\text { 을 } \\
\text { 咅 }\end{array}$ & 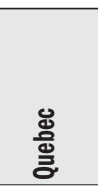 & 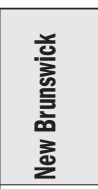 & 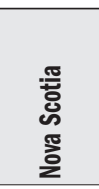 & 몸 & 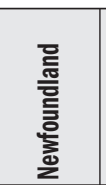 & 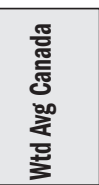 \\
\hline \multicolumn{12}{|l|}{ METRs on R\&D Inputs } \\
\hline Labour & $-39.7 \%$ & $-39.7 \%$ & $-43.1 \%$ & $-46.4 \%$ & $-36.0 \%$ & $-44.7 \%$ & $-43.1 \%$ & $-43.1 \%$ & $-33.0 \%$ & $-43.1 \%$ & $-39.5 \%$ \\
\hline Materials & $-25.8 \%$ & $-28.0 \%$ & $-28.7 \%$ & $-33.9 \%$ & $-23.6 \%$ & $-20.0 \%$ & $-32.0 \%$ & $-32.0 \%$ & $-15.2 \%$ & $-32.0 \%$ & $-23.3 \%$ \\
\hline Contract & $-28.0 \%$ & $-28.0 \%$ & $-32.0 \%$ & $-36.0 \%$ & $-23.6 \%$ & $-34.0 \%$ & $-32.0 \%$ & $-32.0 \%$ & $-20.0 \%$ & $-32.0 \%$ & $-27.8 \%$ \\
\hline Equipment & $-33.0 \%$ & $-35.0 \%$ & $-35.9 \%$ & $-40.5 \%$ & $-31.2 \%$ & $-28.0 \%$ & $-39.0 \%$ & $-38.6 \%$ & $-24.3 \%$ & $-39.1 \%$ & $-30.9 \%$ \\
\hline Overhead & $0.0 \%$ & $0.0 \%$ & $0.0 \%$ & $0.0 \%$ & $0.0 \%$ & $0.0 \%$ & $0.0 \%$ & $0.0 \%$ & $0.0 \%$ & $0.0 \%$ & $0.0 \%$ \\
\hline $\begin{array}{l}\text { METR on } \\
\text { R\&D Costs }\end{array}$ & $-24.3 \%$ & $-24.6 \%$ & $-26.8 \%$ & $-29.5 \%$ & $-21.8 \%$ & $-26.5 \%$ & $-27.2 \%$ & $-27.2 \%$ & $-18.9 \%$ & $-27.2 \%$ & $-23.9 \%$ \\
\hline METR on R\&D & $-61.9 \%$ & $-62.6 \%$ & $-67.5 \%$ & $-72.9 \%$ & $-57.7 \%$ & $-67.1 \%$ & $-68.9 \%$ & $-67.6 \%$ & $-54.0 \%$ & $-69.3 \%$ & $-61.7 \%$ \\
\hline $\begin{array}{l}\text { Required Before } \\
\text { Tax Rate of Return } \\
\text { (10\% after-tax hurdle) }\end{array}$ & $3.81 \%$ & $3.74 \%$ & $3.25 \%$ & $2.71 \%$ & $4.23 \%$ & $3.29 \%$ & $3.11 \%$ & $3.24 \%$ & $4.60 \%$ & $3.07 \%$ & $3.83 \%$ \\
\hline
\end{tabular}

The first five rows in Table 1 present METRs on the individual inputs employed in the creation of intangible R\&D capital - labour, materials, contract R\&D, capital equipment, and overhead. As discussed above, these inputs vary not only in their tax treatment, but in their economic characteristics. These inputs are combined and used in the in-house production of knowledge, which in turn enters the production process by way of new products or processes. To interpret the METRs on the R\&D inputs reported in the table, it is easiest to think of them as measuring the percentage change in the economic cost of employing each input at the margin. ${ }^{14}$ For example, the Canadian weighted average METR on labour employed in R\&D is 39.5 percent. This indicates that the tax system lowers the marginal cost of hiring labour employed in R\&D by just under 40 percent. The fact that this METR is negative, as are all of the input METRs in the table, indicates that the tax system lowers the cost of labour used in $R \& D$; in other words the tax system acts as a subsidy to R\&D inputs. This, of course, is precisely the policy intent, which is to encourage private sector R\&D expenditures by lowering their cost. The variation in the METRs on R\&D inputs across provinces follows from differences in tax credit rates and corporate income tax rates, as well as the presence of other taxes levied on some of the R\&D inputs (such as provincial sales taxes falling on materials). Thus, we see that provinces with higher R\&D credit rates, like Manitoba, have higher effective subsidy rates on all of the $R \& D$ inputs.

Notable in the table is the variation in the METRs across the R\&D inputs within provinces. This is because of differences in the tax treatment and in the nature of the expenditures themselves. Of particular interest is the fact that R\&D labour is the most highly subsidized input into the R\&D process, while overhead expenses are not subsidized (or taxed) at all, bearing a METR of zero. This is due to the proxy treatment of overhead expenses. As indicated above, firms have the option of itemizing actual overhead expenses or claiming 65 percent of labour expenditures as a proxy. Research done by the Secretariat to the Jenkins Panel indicates

\footnotetext{
14 Effective tax rate aficionados should note that these effective tax rates are measured gross of depreciation and are expressed relative to the net-of-tax rate return.
} 
that virtually all corporations claiming the SR\&ED tax credit used the proxy method for overhead expenditures. ${ }^{15}$ As such, the calculations in all of the tables assume that firms use the proxy method. ${ }^{16}$ However, and importantly, this has important implications for the nature of tax subsidy, and for the METRs on labour and overhead. A firm using the proxy method which spends an incremental dollar on R\&D overhead earns no tax credit explicitly (though the expense is fully deductible for income tax purposes); as such the effective credit rate for overhead for proxy using firms is zero. On the other hand, if the firm spends an incremental dollar on R\&D labour, it earns a basic 20-cent federal credit for the labour expenditure and an additional 13-cent credit ( $\$ 1 \times 165 \times .2)$ as a proxy for overhead expenditures. Thus, the basic effective SR\&ED federal tax credit for labour for firms using the proxy method is 33 percent, compared to 20 percent for materials and contract R\&D, and zero for overhead. For non-proxy using firms (of which there are very few), the SR\&ED credit rate is 20 percent across the board. For firms eligible for the 35 percent enhanced credit, the effective federal credit rate for labour is 57.75 percent. The proxy method thus provides a significant additional incentive for R\&D labour, while providing no incentive to invest in overhead type expenses.

Also note that the METRs on materials and contract R\&D are the same in Alberta and all of the GST-harmonized provinces except Quebec, while the METR on materials is higher (less negative) in non-harmonized provinces. This is because materials bear some sales tax due to the non-harmonization of some provincial sales taxes. In Quebec, the METR on labour and contract $R \& D$ is significantly lower (more negative) than other inputs because of the restriction of its provincial R\&D tax credit to wages and contract R\&D. Moreover the METR on capital equipment used in $R \& D$ is slightly lower (more negative) than the current inputs other than labour. This is because along with the federal and provincial R\&D credits, capital expenditures used in $R \& D$ are immediately expensed for tax purposes. While this is also true for current expenditures, immediate deductibility is more valuable for capital expenditures, and results in a greater subsidy, because capital is of enduring value and would normally be depreciated over time. The pre-Budget 2012 system thus slightly favours R\&D capital expenditures over nonlabour current expenditures.

The METR calculations in the next three rows of the table are the focus of attention for most of the rest of the paper. The METR on R\&D Costs aggregates the METRs on the individual $R \& D$ inputs together in a measure of the impact of the tax system on the marginal cost of producing an incremental unit of intangible R\&D capital. To calculate the METR on R\&D costs, an assumption must be made about the R\&D production function, which characterizes the technology underlying the creation of knowledge. As discussed in McKenzie, ${ }^{17}$ it turns out that the METR calculations are not very sensitive to this assumption, and vary only slightly under alternative formulations. ${ }^{18}$

15 See Secretariat to the Expert Review Panel on Research and Development (2011), Assessing the Scientific Research and Experimental Development Tax Credit, at http://rd-review.ca/eic/site/033.nsf/vwapj 14_Assessing_the_SRED_Tax_Credit-eng.pdf/\$FILE/4_Assessing_the_SRED_Tax_Credit-eng.pdf

${ }^{16}$ Calculations assuming that firms itemize overhead expenses are available from the author upon request. They do not substantially change the conclusions that follow.

17 McKenzie (2008). Op. cit.

18 The calculations are based upon a Fixed Proportions (FP) production function, which is a special case in the broader class of Constant Elasticity of Substitution (CES) production functions. The FP function assumes that the elasticity of substitution between R\&D inputs is zero, which means that there is no scope for substitutability across inputs in the production of intangible R\&D. The factor shares underlying the calculations are taken from Expert Panel (2011) op. cit. and are as follows. For large corporations: labour 37.2 percent, capital equipment 4.9 percent, materials 9.6 percent, overhead 28.6 percent, contracts 18.4 percent. For small corporations: labour 46.7 percent, capital equipment 2.6 percent, materials 7.3 percent, overhead 29.5 percent, contracts 13.5 percent. 
As indicated, the METR on R\&D costs measures the percentage change in the marginal cost of producing an incremental unit of intangible $R \& D$ capital within the firm. Thus, on average, for Canada as a whole for large corporations, the pre-Budget 2012 tax system resulted in a 23.9 percent reduction in the marginal cost of producing an incremental unit of intangible $R \& D$ capital. This, of course, is not surprising in light of the negative METRs on the individual $R \& D$ inputs discussed above. There is significant variation in the METR on R\&D costs across provinces, again reflecting differences in tax provisions, primarily R\&D tax credit rates and corporate income tax rates. For example, at -18.9 percent the METR on R\&D Costs in PEI is the highest (least negative) due to the absence of a provincial $R \& D$ tax credit program (but it is still notably negative because of the federal credit), while at -29.5 percent the rate in Manitoba is the lowest because of its high provincial $R \& D$ tax credit rate.

The sixth row in the table reports the METR on intangible R\&D capital. This uses the METR on R\&D costs calculated previously to determine the impact of the tax system on the rate of return on an incremental unit of investment in intangible R\&D capital. As such, the METR on intangible $R \& D$ capital captures the overall incentive effects of the tax system with respect to investment in R\&D.

The intuition behind the METR on intangible R\&D capital is straightforward. It is presumed that there is a minimum required after-tax hurdle rate of return that all $\mathrm{R} \& \mathrm{D}$ projects must achieve in order to be considered viable by businesses - this is referred to as the net-of-tax rate of return. All R\&D projects (which employ the R\&D inputs discussed above) must generate at least this net-of-tax hurdle rate of return, and the marginal project will generate it exactly, just breaking even in an economic sense. The gross-of-tax rate of return is the beforetax rate of return required to achieve the after-tax hurdle rate of return. The METR on intangible R\&D capital in Table 1 measures the difference between the gross- and net-of-tax rates of return on a marginal $R \& D$ project expressed as a percentage of the net-of-tax rate of return. For example, say the required after-tax hurdle rate of return on an investment project is 10 percent, and the before-tax rate of return required to achieve this after-tax hurdle rate of return is 12 percent; then the METR is 20 percent (calculated as (12 percent - 10 percent) / 10 percent). This means that the before-tax rate of return is 20 percent higher than the minimum after-tax rate of return required by the business, and the tax system therefore discourages investment. ${ }^{19}$

As one would expect in light of the previous analysis, the METRs on intangible R\&D capital for large corporations in Table 1 are in fact negative across the board, due to the tax incentives offered for expenditures used in R\&D. This means that the tax system in Canada is such that the required before-tax rate of return on a marginal $R \& D$ project is lower than the associated after-tax hurdle rate of return, and investment in R\&D capital is subsidized at the margin. The weighted average METR on intangible R\&D capital for large corporations in Canada preBudget 2012 is -61.7 percent.

19 Both net- and gross-of-tax rates of return are measured net of depreciation, which is assumed to be 10 percent for R\&D capital. Moreover, the calculations differ slightly from standard METR measures for tangible capital in that they are expressed relative to the net-of-tax rate of return, rather than the gross-of-tax rate of return. 
The final row in the table reports the before-tax rate of return on an incremental R\&D project required to earn an after-tax hurdle rate of return of 10 percent. Because the METRs on intangible $R \& D$ capital in the previous row are negative, the required before-tax rates of return are less than 10 percent. For example, for Canada as a whole, the weighted average required before-tax rate of return, which earns 10 percent after tax, is about 3.8 percent (calculated as 10 percent $*(1-.617)=3.83$ percent $)$.

The size of the subsidy to investment in $\mathrm{R} \& \mathrm{D}$ varies considerably across provinces, ranging from a low of -54.0 percent in PEI to a high of -72.9 percent in Manitoba. The before-tax rate of return on a marginal $R \& D$ project for a large corporation required to yield the minimum after-tax rate of return of 10 percent can be as low as $2.7 \%$ percent in Manitoba or as high as 4.6 percent in PEI. This suggests the possibility of significant inter-jurisdictional distortions in the allocation of R\&D effort across the country.

It is evident from the analysis that pre-Budget 2012 a substantial subsidy for investment in intangible R\&D existed in all provinces. However, as will now be seen, it is modest compared to the size of the subsidy for small (CCPC) corporations.

\section{SMALL CORPORATIONS}

Table 2 contains similar calculations for CCPCs, so-called small corporations. As for large corporations, the METRs in the table are combined METRs, reflecting both the federal and provincial tax system in each province, it is assumed that none of the expenditure limits for provincial tax credits are binding in the provinces that have them, and all corporations are fully taxable and able to claim all credits and deductions. ${ }^{20}$

TABLE 2: R\&D METRS, SMALL CORPORATIONS, PRE-BUDGET 2012

\begin{tabular}{|c|c|c|c|c|c|c|c|c|c|c|c|}
\hline & 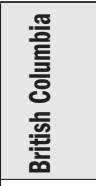 & 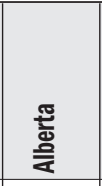 & 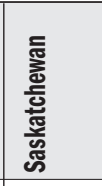 & 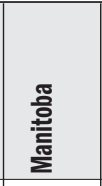 & $\begin{array}{l}\text { 옳 } \\
\text { ث્心 } \\
\end{array}$ & $\begin{array}{l}\text { ष्ँ } \\
\text { పे }\end{array}$ & 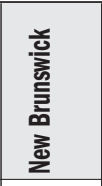 & 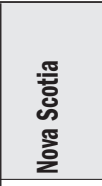 & $\overline{\underline{a}}$ & 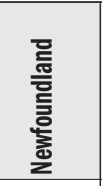 & 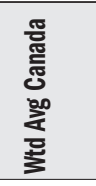 \\
\hline \multicolumn{12}{|l|}{ METRs on R\&D Inputs } \\
\hline Labour & $-62.0 \%$ & $-62.0 \%$ & $-64.1 \%$ & $-66.2 \%$ & $-62.0 \%$ & $-73.6 \%$ & $-64.1 \%$ & $-64.1 \%$ & $-57.8 \%$ & $-64.1 \%$ & $-65.6 \%$ \\
\hline Materials & $-39.7 \%$ & $-41.5 \%$ & $-42.0 \%$ & $-46.3 \%$ & $-41.5 \%$ & $-35.0 \%$ & $-44.8 \%$ & $-44.8 \%$ & $-31.1 \%$ & $-44.8 \%$ & $-39.5 \%$ \\
\hline Contract & $-41.5 \%$ & $-41.5 \%$ & $-44.8 \%$ & $-48.0 \%$ & $-41.5 \%$ & $-47.2 \%$ & $-44.8 \%$ & $-44.8 \%$ & $-35.0 \%$ & $-44.8 \%$ & $-43.4 \%$ \\
\hline Equipment & $-44.2 \%$ & $-46.2 \%$ & $-46.6 \%$ & $-50.3 \%$ & $-44.4 \%$ & $-40.7 \%$ & $-49.3 \%$ & $-49.3 \%$ & $-36.4 \%$ & $-49.3 \%$ & $-43.5 \%$ \\
\hline Overhead & $0.0 \%$ & $0.0 \%$ & $0.0 \%$ & $0.0 \%$ & $0.0 \%$ & $0.0 \%$ & $0.0 \%$ & $0.0 \%$ & $0.0 \%$ & $0.0 \%$ & $0.0 \%$ \\
\hline $\begin{array}{l}\text { METR on } \\
\text { R\&D Costs }\end{array}$ & $-38.7 \%$ & $-38.9 \%$ & $-40.4 \%$ & $-42.3 \%$ & $-38.9 \%$ & $-44.5 \%$ & $-40.7 \%$ & $-40.7 \%$ & $-35.1 \%$ & $-40.7 \%$ & $-40.7 \%$ \\
\hline METR on R\&D & $-85.3 \%$ & $-86.7 \%$ & $-89.3 \%$ & $-92.4 \%$ & $-87.1 \%$ & $-99.6 \%$ & $-90.7 \%$ & $-90.6 \%$ & $-78.1 \%$ & $-90.6 \%$ & $-90.9 \%$ \\
\hline $\begin{array}{l}\text { Required Before } \\
\text { Tax Rate of Return } \\
\text { (10\% after-tax hurdle) }\end{array}$ & $1.47 \%$ & $1.33 \%$ & $1.07 \%$ & $0.76 \%$ & $1.29 \%$ & $0.04 \%$ & $0.93 \%$ & $0.94 \%$ & $2.19 \%$ & $0.94 \%$ & $0.91 \%$ \\
\hline
\end{tabular}

${ }^{20}$ For CCPCs federal R\&D tax credits associated with current expenditures are 100 percent refundable, while for capital expenditures the refundability rate is 40 percent. Most provinces also have refundability provisions for CCPCs. 
Moving directly to the second last row in Table 2, which presents the METRs on intangible R\&D capital for small corporations pre-Budget 2012, it is immediately evident that the effective subsidy rates are substantially larger than for large corporations. The weighted average METR on intangible capital for Canada is -90.9 percent. As seen in the last row, if the required after-tax required rate of return is 10 percent, this means that the before-tax hurdle rate of return on an $R \& D$ project for a small business is just under one percent (actually 0.91 percent). Again, there is substantial variation across the provinces. However, with the exception of PEI, in most of the provinces the required before-tax rate of return on a marginal R\&D investment is just under one percent. Indeed in Quebec the METR on intangible R\&D capital is almost negative 100 percent. This means that the before-tax required rate of return on a marginal $\mathrm{R} \& \mathrm{D}$ project is close to zero percent.

\section{Budget 2012}

Table 3 reports the various METRs for the post-Budget 2012 system for large corporations. The calculations assume that the provincial governments follow the federal government's lead and eliminate the credit on R\&D capital equipment, reduce the eligibility of contract expenditures to 80 percent, and reduce the proxy rate for overhead expenditures to 55 percent. As would be expected given these changes, and of course the five-percentage-point reduction in the general federal credit for large corporations, the weighted average Canadian METR on intangible R\&D capital for large corporations rises from a pre-Budget 2012 value of -61.7 percent to -49.0 percent post-budget. A marginal $R \& D$ project required to earn a 10 percent rate of return after-tax must now earn a before-tax rate of return of 5.1 percent, compared to 3.8 percent pre-budget. While this is still a substantial subsidy, it is significantly reduced from the pre-budget level, which was the policy intent.

\section{TABLE 3: R\&D METRS, LARGE CORPORATIONS, POST-BUDGET 2012}

\begin{tabular}{|c|c|c|c|c|c|c|c|c|c|c|c|}
\hline & 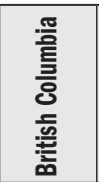 & $\begin{array}{l}\frac{\pi}{5} \\
\frac{\mathrm{g}}{2}\end{array}$ & 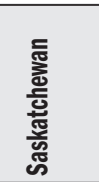 & 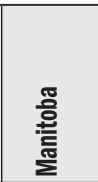 & $\begin{array}{l}\text { 율 } \\
\text { 害 }\end{array}$ & $\begin{array}{l}\text { ष्ँ } \\
\text { 音 }\end{array}$ & 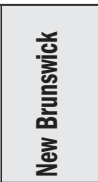 & 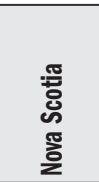 & $\overline{\underline{a}}$ & $\begin{array}{l}\text { 플 } \\
\text { 흫 } \\
\text { 言 } \\
\text { 흘 }\end{array}$ & 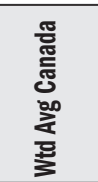 \\
\hline \multicolumn{12}{|l|}{ METRs on R\&D Inputs } \\
\hline Labour & $-30.9 \%$ & $-30.9 \%$ & $-34.8 \%$ & $-38.6 \%$ & $-26.7 \%$ & $-36.7 \%$ & $-34.8 \%$ & $-34.8 \%$ & $-23.3 \%$ & $-34.8 \%$ & $-30.7 \%$ \\
\hline Materials & $-21.1 \%$ & $-23.5 \%$ & $-24.2 \%$ & $-29.8 \%$ & $-18.8 \%$ & $-15.0 \%$ & $-27.8 \%$ & $-27.8 \%$ & $-9.9 \%$ & $-27.8 \%$ & $-18.5 \%$ \\
\hline Contract & $-19.0 \%$ & $-19.0 \%$ & $-22.6 \%$ & $-26.1 \%$ & $-15.2 \%$ & $-24.3 \%$ & $-22.6 \%$ & $-22.6 \%$ & $-12.0 \%$ & $-22.6 \%$ & $-18.9 \%$ \\
\hline Equipment & $-7.0 \%$ & $-9.8 \%$ & $-5.7 \%$ & $-7.1 \%$ & $-10.0 \%$ & $-10.1 \%$ & $-10.2 \%$ & $-9.8 \%$ & $-5.4 \%$ & $-10.4 \%$ & $-9.7 \%$ \\
\hline Overhead & $0.0 \%$ & $0.0 \%$ & $0.0 \%$ & $0.0 \%$ & $0.0 \%$ & $0.0 \%$ & $0.0 \%$ & $0.0 \%$ & $0.0 \%$ & $0.0 \%$ & $0.0 \%$ \\
\hline $\begin{array}{l}\text { METR on } \\
\text { R\&D Costs }\end{array}$ & $-17.6 \%$ & $-18.0 \%$ & $-19.9 \%$ & $-22.7 \%$ & $-15.2 \%$ & $-20.3 \%$ & $-20.5 \%$ & $-20.5 \%$ & $-12.2 \%$ & $-20.5 \%$ & $-17.4 \%$ \\
\hline METR on R\&D & $-48.8 \%$ & $-49.5 \%$ & $-54.3 \%$ & $-59.6 \%$ & $-44.8 \%$ & $-55.0 \%$ & $-55.8 \%$ & $-54.4 \%$ & $-41.3 \%$ & $-56.3 \%$ & $-49.0 \%$ \\
\hline $\begin{array}{l}\text { Required Before } \\
\text { Tax Rate of Return } \\
\text { (10\% after-tax hurdle) }\end{array}$ & $5.12 \%$ & $5.05 \%$ & $4.57 \%$ & $4.04 \%$ & $5.52 \%$ & $4.50 \%$ & $4.42 \%$ & $4.56 \%$ & $5.87 \%$ & $4.37 \%$ & $5.10 \%$ \\
\hline
\end{tabular}


Another notable feature of the policy change for large corporations is the increased variability in the METRs on the R\&D inputs. As discussed above, prior to Budget 2012 capital equipment used in $R \& D$ was subsidized to roughly the same extent as non-overhead current expenditures (except in Quebec). Under the new regime, which restricts the R\&D tax credit to current expenditures, the subsidy rate on equipment drops significantly. For all of Canada, the effective subsidy rate on capital used in R\&D is just under 10 percent (a METR of -9.7 percent), compared to subsidy rates for current expenditures ranging from 18.5 percent to 30.7 percent. $^{21}$ Moreover, the subsidy rate on R\&D labour remains markedly higher (the METR is more negative) than other R\&D inputs (this is largely due to Quebec, which targets its $R \& D$ tax credit to wages).

Another way to see this is to compare the coefficient of variation on the input METRs for large corporations pre- and post-budget. ${ }^{22}$ The pre-budget coefficient of variation is 0.55 ; postbudget it rises to 0.66 . It is thus evident that the post-Budget 2012 regime, while lowering the overall level of the subsidy provided to $\mathrm{R} \& \mathrm{D}$, also introduces distortions into the production of knowledge within firms. In particular, the new system favours labour-intensive R\&D relative to capital-intensive R\&D even more than the old system did. This will also lead to inter-sectoral distortions between types of $\mathrm{R} \& \mathrm{D}$ that are inherently labour- or capital-intensive.

Table 4 presents the post-Budget 2012 METRs for small (CCPC) corporations. While the enhanced federal R\&D tax credit rate for small businesses remains unchanged at 35 percent, the elimination of the credit for capital expenditures, the restriction on the eligibility of contract expenditures, and the reduction in the proxy rate for overhead expenditures reduce the size of the subsidy slightly for small corporations. Table 4 indicates that the post-budget weighted average 2012 METR on intangible R\&D capital for small corporations rises to -84.2 percent, compared to -90.9 percent under the pre-budget regime. The before-tax rate of return on a marginal R\&D project required to yield 10 percent on an after-tax basis rises to about 1.6 percent from just below one percent pre-budget.

TABLE 4: R\&D METRS, SMALL CORPORATIONS, POST-BUDGET 2012

\begin{tabular}{|c|c|c|c|c|c|c|c|c|c|c|c|}
\hline & 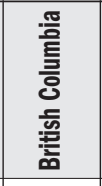 & 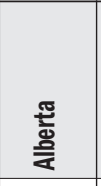 & 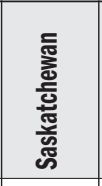 & 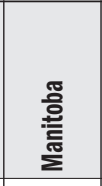 & $\begin{array}{l}\text { 을 } \\
\text { 롱 }\end{array}$ & $\begin{array}{l}\text { ष्ँ } \\
\text { के }\end{array}$ & $\begin{array}{l}\text { 흘 } \\
\text { 产 } \\
\text { 言 } \\
\text { 竞 } \\
\end{array}$ & $\begin{array}{l}\text { 要 } \\
\text { 造 } \\
\text { 䓂 } \\
\end{array}$ & $\bar{\square}$ & 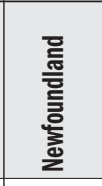 & 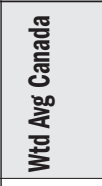 \\
\hline \multicolumn{12}{|l|}{ METRs on R\&D Inputs } \\
\hline Labour & $-58.8 \%$ & $-58.8 \%$ & $-61.1 \%$ & $-63.4 \%$ & $-58.8 \%$ & $-71.4 \%$ & $-61.1 \%$ & $-61.1 \%$ & $-54.3 \%$ & $-61.1 \%$ & $-62.8 \%$ \\
\hline Materials & $-39.7 \%$ & $-41.5 \%$ & $-42.0 \%$ & $-46.3 \%$ & $-41.5 \%$ & $-35.0 \%$ & $-44.8 \%$ & $-44.8 \%$ & $-31.1 \%$ & $-44.8 \%$ & $-39.5 \%$ \\
\hline Contract & $-33.8 \%$ & $-33.8 \%$ & $-36.6 \%$ & $-39.5 \%$ & $-33.8 \%$ & $-38.8 \%$ & $-36.6 \%$ & $-36.6 \%$ & $-28.0 \%$ & $-36.6 \%$ & $-35.4 \%$ \\
\hline Equipment & $-4.7 \%$ & $-8.0 \%$ & $-3.3 \%$ & $-4.5 \%$ & $-8.2 \%$ & $-8.8 \%$ & $-8.2 \%$ & $-8.2 \%$ & $-2.2 \%$ & $-8.2 \%$ & $-8.0 \%$ \\
\hline Overhead & $0.0 \%$ & $0.0 \%$ & $0.0 \%$ & $0.0 \%$ & $0.0 \%$ & $0.0 \%$ & $0.0 \%$ & $0.0 \%$ & $0.0 \%$ & $0.0 \%$ & $0.0 \%$ \\
\hline $\begin{array}{l}\text { METR on } \\
\text { R\&D Costs }\end{array}$ & $-35.2 \%$ & $-35.4 \%$ & $-36.8 \%$ & $-38.6 \%$ & $-35.4 \%$ & $-41.5 \%$ & $-37.1 \%$ & $-37.1 \%$ & $-31.6 \%$ & $-37.1 \%$ & $-37.4 \%$ \\
\hline METR on R\&D & $-78.0 \%$ & $-79.6 \%$ & $-82.0 \%$ & $-85.0 \%$ & $-80.1 \%$ & $-93.6 \%$ & $-83.6 \%$ & $-83.4 \%$ & $-71.0 \%$ & $-83.4 \%$ & $-84.2 \%$ \\
\hline $\begin{array}{l}\text { Required Before } \\
\text { Tax Rate of Return } \\
\text { (10\% after-tax hurdle) }\end{array}$ & $2.20 \%$ & $2.04 \%$ & $1.80 \%$ & $1.50 \%$ & $1.99 \%$ & $0.64 \%$ & $1.64 \%$ & $1.66 \%$ & $2.90 \%$ & $1.66 \%$ & $1.58 \%$ \\
\hline
\end{tabular}

21 The METR on R\&D capital inputs remains negative even with the elimination of the credit because of the immediate deduction of the expenditure for a capital input.

${ }^{22}$ The coefficient of variation is the ratio of the standard deviation of the METRs on the inputs, divided by the mean. 
Moreover, the budget changes introduce additional variability into the input METRs for small corporations - the Canadian average METR on R\&D labour is -62.8 percent versus -8.0 percent for capital - indeed even more so than is the case for large corporations. In this connection, it important to note that this also contributes to the increased gap in the overall METR on intangible capital between small and large corporations post-Budget 2012. While $R \& D$ equipment accounts for only 2.5 percent of $R \& D$ spending on average for small corporations, the share for large corporations is double that, at five percent. ${ }^{23}$ Moreover, contract R\&D accounts for 13.5 percent of spending for small businesses, but 18.4 percent for large corporations. ${ }^{24}$ Budget 2012 eliminates the tax credit for R\&D equipment and restricts it to 80 percent of contract spending. This disproportionately disadvantages large corporations and further increases the gap in the R\&D subsidy rate between large and small firms.

To summarize, Budget 2012 results in an increase in the METRs on intangible R\&D capital for both large and small corporations. In doing so, however, it changes the configuration of METRs, increasing distortions in the use of different R\&D inputs, and significantly increasing the gap between the effective R\&D subsidy rate on small versus large corporations.

\section{The Minutiae of Provincial Tax Credits}

As indicated above, some provinces introduce nuances to their R\&D tax credit programs. These nuances take the form of expenditure limits, higher credits for particular types of expenditures, etc. As illustrated in Table 5, these features can significantly alter the nature of the subsidies.

TABLE 5: R\&D METRS, LARGE CORPORATIONS, PROVINCIAL LIMITS AND PROGRAMS, POST-BUDGET 2012

\begin{tabular}{|l|c|c|}
\hline & METR on R\&D Costs & METR on R\&D Capital \\
\hline Alberta (10\%) & & $-49.5 \%$ \\
\$4 m Expenditure Limit Not Binding & $-18.0 \%$ & $-39.7 \%$ \\
\$4 Expenditure Limit Binding & $-12.9 \%$ & $-44.8 \%$ \\
Ontario & & \\
Regular R\&D Tax Credit (4.5\%) & $-15.2 \%$ & $-50.1 \%$ \\
Research Institute Tax Credit (20\% for contract R\&D) & \\
$\quad$ \$20 m Expenditure Limit Not Binding & $-17.9 \%$ & $-44.8 \%$ \\
$\quad$ \$20 m Expenditure Limit Binding & $-15.2 \%$ & $-55.0 \%$ \\
Quebec & & $-66.7 \%$ \\
Regular R\&D Tax Credit (17.5\%) & $-20.5 \%$ & $-23.8 \%$ \\
Credit for Contract R\&D with Eligible Institutions (35\%) & \\
\hline
\end{tabular}

1. Available for contract $R \& D$ with eligible research institutes, including post-secondary and hospital research institutions and prescribed non-profit research organizations.

2. Available for contract $R \& D$ with eligible entities, including universities, public research centres and private research consortiums.

${ }^{23}$ See footnote 15 .

${ }^{24}$ Ibid. It bears mentioning that the Jenkins Report recommended restricting the tax credit to the labour component of contract R\&D, which they assume to be 50 percent. This recommendation seems to have been motivated by a desire to reduce compliance costs and the presumption that profits may be embedded in contracting costs. This rationale does not seem to me to be well-motivated. Regardless of the presence of embedded profits and compliance costs associated with contract $R \& D$, the reduction in the expenditures eligible for the credit changes the relative price of contract $\mathrm{R} \& \mathrm{D}$, which will introduce production inefficiencies in the production of intangible $\mathrm{R} \& \mathrm{D}$ capital. 
The table presents the METR on R\&D costs and the METR on intangible R\&D capital for large corporations under the post-Budget 2012 regime for Alberta, Ontario and Quebec. The tax credit programs in the other provinces are for the most part straightforward and unrestricted.

Alberta imposes an expenditure limit of $\$ 4$ million; $R \& D$ expenditures over the limit receive no provincial tax credit. As seen in the table, this generates a ten-percentage-point difference in the effective subsidy rate on a marginal investment in $\mathrm{R} \& \mathrm{D}$, depending upon whether a corporation is above or below the expenditure limit.

Ontario provides an enhanced tax credit of 20 percent for contract $R \& D$ with eligible research institutes, with a \$20 million expenditure cap. For corporations under the cap, the METR on intangible $R \& D$ is five percentage points lower (the subsidy rate is higher).

Quebec also offers an enhanced credit for contract R\&D with eligible research institutes, but with no expenditure limit. This lowers the METR on intangible R\&D capital by about 12 percentage points.

\section{POLICY DISCUSSION AND IMPLICATIONS}

The METR calculations presented above provide fodder for the discussion of several policy issues related to $\mathrm{R} \& \mathrm{D}$ subsidies delivered through the tax system. The first concerns the overall level of the R\&D subsidy in Canada. While it is difficult to say what the optimal subsidy for R\&D should be - this will depend upon the magnitude of the market failures associated with R\&D, most particularly the size of the knowledge spillovers, as well as the cost of raising the public revenue to fund the subsidy, etc. ${ }^{25}$ - it seems clear that the effective tax subsidy rate in Canada prior to Budget 2012 was significant, and that it remains so after the budget. Given that the R\&D tax subsidies offered in Canada have been identified as among the most generous in the world, a reduction in the effective subsidy rates may well have been justified. Moreover, the budget redirected some of the cost savings to the government arising from the reduced $R \& D$ tax credit to other $R \& D$ initiatives, of the nature of direct support programs. On the whole, federal R\&D support declines as a part of the budget, though smaller firms gain slightly. ${ }^{26}$

However, and importantly, the METR analysis performed here indicates that the budget significantly altered the relative subsidies offered to large versus small firms and between different types of $R \& D$ expenditures. This is problematic for several reasons.

\footnotetext{
25 See, for example, Dahlby, Bev (2005), “A Framework for Evaluating Provincial R\&D Tax Subsidies," Canadian Public Policy Vol. 31 No. 1, March, 45-58; Parsons, Mark and Nicholas Phillips (2007), "An Evaluation of the Federal Tax Credit for Scientific Research and Experimental Development," Department of Finance Working Paper 2007-08; Lester (2012) op. cit.

${ }^{26}$ See Lester (2012) ibid.
} 
The METR calculations show that the budget increased the variation in the effective tax rates on the inputs used in the creation of intangible R\&D capital (knowledge). In particular, current costs associated with R\&D, most particularly labour, now enjoy a much higher effective subsidy rate than capital employed in $R \& D$. While capital accounts for a relatively small share of $R \& D$ expenditures in aggregate, suggesting that this change in and of itself leads to only a modest reduction in the overall METR on intangible R\&D capital, there is no good policy reason to favour current over capital expenditures in the creation of $R \& D$. In particular, there is no evidence that the social return to labour-intensive R\&D differs from that on capitalintensive $R \& D$. The introduction of increased variation in the effective subsidy rate across inputs distorts the $R \& D$ production decisions of firms and favours labour-intensive $R \& D$ processes over capital-intensive processes. Moreover, while overall the share of capital expenditures into the production of intangible $R \& D$ may be low, for some firms and some sectors it is higher, suggesting a further distortion across firms, sectors, and types of R\&D. A system that is closer to neutrality across R\&D inputs would be more desirable.

The justification for eliminating the SR\&ED credit for capital expenditures in both the budget documents and the Jenkins Report was the desire to reduce compliance and administration costs. This suggests a trade-off between the reduction in compliance costs and the increased distortion associated with the bias against capital expenditures. While this is a legitimate concern in theory, we know little about the size of extent of this trade-off and the complete elimination of the credit for R\&D capital seems to be a rather blunt approach to the problem. ${ }^{27}$

In this regard, an important part of the budget changes was to reduce the overhead proxy from 65 percent to 55 percent of R\&D labour costs. The apparent justification for the proxy method in the first place was to reduce compliance costs in light of the difficulties of measuring overhead expenses associated with R\&D. The Jenkins Report ${ }^{28}$ identified this as being unduly rich, and in this context the reduction to 55 percent may well be justified. Moreover, as discussed above, the proxy approach amounts to an increase in the effective tax credit rate for labour, which biases the system in favour of labour-intensive R\&D. The reduction in the proxy in the budget therefore helps to some extent in this regard. More to the point, if overhead expenditures are thought to be a legitimate, and productive, part of the R\&D process, a better approach may well have been to eliminate the proxy altogether and require overhead expenses to be itemized. Of course, and again, the trade-off here is that this would increase compliance costs.

Perhaps more importantly, the budget also significantly increases the gap between the effective subsidy rates on intangible R\&D between large and small firms. Though the METR for both large and small firms rises under the budget (the subsidy falls), the rise in the METR on intangible R\&D capital is much bigger for large firms than small firms: pre-Budget 2012 the effective subsidy rate for small corporations was 1.47 times larger than that for large corporations, post-Budget 2012 this ratio increases to 1.72 . This is primarily due to the

\footnotetext{
27 Having said this, it should be noted that other countries, for example the US and the Netherlands, also restrict R\&D tax credits to non-capital expenditures.

${ }^{28}$ Public Works and Government Services Canada (2011), op. cit. Box 6.5, p. 6-11.
} 
reduction in the federal credit for large firms from 20 percent to 15 percent, while the enhanced credit for small firms was maintained at 35 percent. However, the R\&D subsidy gap between large and small firms was also exacerbated by the budget due to differences in the distribution of spending across R\&D inputs, and the different treatment of inputs under the budget. The share of total R\&D spending on equipment is twice as high for large firms relative to small firms, while the share of contract R\&D is about 1.36 times higher. As discussed above, both of these inputs saw a decrease in the effective subsidy rate relative to other inputs. Moreover, small corporations devote a significantly higher proportion of their R\&D spending to labour, which the analysis shows receive an increase in the relative rate of subsidy post-Budget 2012. These changes further exacerbate the R\&D subsidy gap in favour of small corporations.

Given the clear policy decision on the part of the federal government to shift government support for R\&D away from large firms towards small firms - both via the changes in the tax system discussed here and through the shift to direct expenditures targeted to small corporations - an obvious question is whether this is justifiable from an economic point of view. This hinges to a large extent on the presence of knowledge spillovers emanating from $\mathrm{R} \& \mathrm{D}$ discussed above.

Before turning to this, some summary statistics are useful. According to Industry Canada, small businesses contribute just under 30 percent to GDP in Canada, while accounting for about 25 percent of total R\&D expenditures. ${ }^{29}$ This suggests that small businesses are punching slightly below their weight in terms of overall $R \& D$ effort. However, as a percentage of revenues small businesses spend much more on R\&D than do large firms - about five percent for firms employing less than 100 people versus one percent for firms employing greater than $5000 .^{30}$ On the basis of this, it is not clear whether or not small businesses are more or less innovative than large firms.

But this is not the point. As discussed above, the policy case for subsidizing R\&D hinges largely on the presence of externalities in the form of knowledge spillovers. Whether small firms are more or less innovative than large firms, or vice versa, is not the issue. What matters is the extent to which R\&D generates non-appropriable spillover benefits and, in particular, whether these benefits are higher or lower for small firms. There is not a great deal of empirical evidence on this front, which in and of itself calls into question the higher effective subsidy rates for small corporations - absent convincing evidence to the contrary, what is the justification for the much higher subsidy rate for small businesses? However, a recent paper by Nicholas Bloom, Mark Schankerman and John Van Reenan, referred to above, uses firm level data from the US to address this issue directly. ${ }^{31}$ They find that the spillovers generated by small businesses in their sample are significantly lower than those for large corporations. They suggest that the reason for this is small firms tend to operate in technological niches. Because fewer firms operate in these niches, the scope for knowledge spillovers is limited. The authors conclude that, "this suggests that policymakers should reconsider their strong support for higher rates of R\&D tax credits for smaller firms, at least on the basis of knowledge spillovers." 32

\footnotetext{
29 See Industry Canada (2010), Key Small Business Statistics - July 2010, at http://www.ic.gc.ca/eic/site/sbrprppe.nsf/eng/rd02489.html

30 Ibid.

31 Bloom, Schankerman and Van Reenan (2010) op. cit.

32 Ibid, page 3.
} 
Some have invoked other market failures thought to be associated with small firms to justify a higher subsidy rate for R\&D for small businesses. These typically take the form of informational market failures and lack of access to financial capital. As suggested by Douglas Holtz-Eatkin, and others, addressing these market failures through instruments other than an enhanced tax credit may be more appropriate. ${ }^{33}$ For example, the fact that the SR\&ED tax credit is refundable for CCPCs (see footnote 14) may be viewed as a policy response to market failures associated with lack of access to capital for small, start-up corporations. ${ }^{34}$

It bears mentioning that the gap between the METRs on R\&D between large and small firms is a measure of the bias towards small firms, but it does not convey the disincentive for small firms to grow when they start to reach the phase-out range for the enhanced credit. It also does not convey the disincentive that the system creates for a CCPC to go public. This is ironic because going public may increase the firm's access to capital, but at the cost of losing the refundable enhanced credit that is (sometimes) justified on the basis that CCPCs have difficulty accessing capital. The METR calculations are based on marginal changes in the capital stock, and do not convey the disincentives associated with this type of discrete change in the firm's status or size. ${ }^{35}$

It is noteworthy that the 2012 Economic Survey of Canada recently issued by the OECD expressed similar concerns to those voiced above. More specifically the OECD report concluded that:

Government support to R\&D should focus more on sharpening incentives and raising performance; the higher current tax subsidy rate for small domestic firms should be unified at the lower large firm rate to encourage firms to attain the scale needed to adopt innovations. Savings could be used to keep capital costs in the eligible base to avoid creating distortions across different technologies. ${ }^{36}$

Finally, another key issue identified in the analysis is the plethora of effective subsidy rates that exist for R\&D across the country, as provinces offer their own versions of the R\&D tax credit. Even within provinces METRs can vary widely, depending upon the eligibility for certain types of expenditures and the presence of tresholds. It is fair to say that Canada is a veritable patchwork of tax incentives for R\&D. This variation encourages the inefficient allocation of R\&D across provinces and sectors and, again, between large and small businesses.

33 Holtz-Eakin, D. (1995), "Should Small Business be Tax-Favored?," National Tax Journal Vol. 48(3), 387-95. See also Chen, Duanjie and J. Mint (2011), Small Business Taxation: Revamping Incentives to Encourage Growth, SPP Research Paper Vol. 4, Issue 7, May 2011.

34 As mentioned previously, the METR calculations undertaken here presume full taxability (or full loss offsetting) on the part of corporations. In principle it is possible to incorporate imperfect loss offsets into the calculations, but this requires detailed information on the pattern of tax losses on the part of firms which I am do not have access to. See Mintz, Jack (1988), “An Empirical Estimate of Corporate Tax Refundability and Effective Tax Rates,” The Quarterly Journal of Economics 103(1), 225-31.

35 For a discussion of some of these issues see Chen and Mintz (2011) op. cit.

36 OECD (2012), Economic Survey of Canada 2012. 
Some of this is inevitable in a federal country such as Canada, where both the national and provincial governments have jurisdiction over tax policy. However, in previous work ${ }^{37} \mathrm{I}$ conjectured that to the extent that $\mathrm{R} \& \mathrm{D}$ investment is mobile across the provinces, a possible outcome is that the resulting subsidy rates are too high as provinces engage in a race to the top in subsidies to attract mobile R\&D. A possible role for the federal government in this case is to lean against this tendency on the part of the provinces by lowering its subsidy rate on $R \& D$ (or even tax it!). Viewed in this light the reductions in the federal R\&D tax credit, and shifting to more direct support for $\mathrm{R} \& \mathrm{D}$, may well be appropriate. However, the analysis conducted here suggests that this could have been done more effectively. In particular, a better approach would have been to lower the overall subsidy rate across the board in a less distortionary fashion, one that treated all types of $\mathrm{R} \& \mathrm{D}$ inputs and large and small corporations in a more uniform and neutral manner.

37 McKenzie, K.J. (2006), "Giving with One Hand, Taking Away with the Other: Canada's Tax System and Research and Development," C.D. Howe Institute Commentary, No. 240, October. 


\section{References}

Bernstein, Jeff (1988), "Costs of Production, Intra-and Interindustry R\&D Spillovers: Canadian Evidence,” Canadian Journal of Economics 21(May): 324-347.

Bernstein, Jeff (1989), "The Structure of Canadian Inter-Industry R\&D Spillovers, and the Rates of Return to R\&D," Journal of Industrial Economics 37(March): 315-328.

Bernstein, Jeff (1996), "International R\&D Spillovers between Industries in Canada and the United States, Social Rates of Return and Productivity Growth," Canadian Journal of Economics 29(April): S463-S467.

Bloom, Nicholas, Mark Shankerman, John Van Reenan (2010), "Identifying Technology Spillovers and Product Market Rivalry," Stanford University, mimeo.

Boadway, Robin and Jean-Francois Tremblay (2005), "Public Economics and Start-up Entrepreneurs," Venture Capital, Entrepreneurship and Public Policy, Kanniainen, V. and C. Keuschnigg, MIT Press, 181-219.

Chen, Duanjie and Jack Mintz (2011), Canada's 2010 Tax Competitiveness Ranking: Moving to the Average but Biased Against Services, SPP Research Paper Vol. 4, Issue 2, February 2011. The School of Public Policy, University of Calgary.

Chen, Duanjie and J. Mint (2011), Small Business Taxation: Revamping Incentives to Encourage Growth, SPP Research Paper Vol. 4, Issue 7, May 2011.

Dahlby, Bev (2005), “A Framework for Evaluating Provincial R\&D Tax Subsidies," Canadian Public Policy Vol. 31 No. 1, March, 45-58.

Secretariat to the Expert Review Panel on Research and Development (2011), Assessing the Scientific Research and Experimental Development Tax Credit, at http://rd-review.ca/eic/site/033.nsf/vwapj 14_Assessing_the_SRED_Tax_Credit-eng.pdf/\$FILE/4_Assessing_the_SRED_Tax_Credit-eng.pdf

Gordon, K. and H. Tchilinguirian (1998), "Marginal Effective Tax Rates on Physical, Human and R\&D Capital,” OECD Economics Department Working Paper 199.

Griffith, R., D. Sandler and J. Van Reenen (1995), “Tax Incentives for R\&D,” Fiscal Studies, Vol. 16, no. 2, 21-44.

Griffith, R. (2000), "How Important is Business R\&D for Economic Growth and Should the Government Subsidize It?," Institute for Fiscal Studies Briefing Note No. 12.

Griliches, Z. (1992), “The Search for R\&D Spillovers,” Scandinavian Journal of Economics Vol. 94, 29-47.

Holtz-Eakin, D. (1995), "Should Small Business be Tax-Favored?," National Tax Journal Vol. 48(3), 387-95.

Industry Canada (2010), Key Small Business Statistics - July 2010, at http://www.ic.gc.ca/eic/site/sbrprppe.nsf/eng/rd02489.html.

KPMG (2011), Federal and Provincial Research and Development Tax Incentives, at http://www.kpmg.com/Ca/en/IssuesAndInsights/ArticlesPublications/TaxRates/Federal\%20and\%20Provi ncial\%20Research\%20and\%20Development\%20Tax\%20Incentives.pdf

Lester, John (2012), "Support for Business R\&D in Budget 2012: Two Steps Forward and One Back," mimeo.

Mackie, J. (2002), "Unfinished Business of the 1986 Tax Reform: An Effective Tax Rate Analysis of Current Issues in the Taxation of Capital Income," National Tax Journal, Vol. 55, 293-337. 
McKenzie, K.J. (2005), “Tax Subsidies for R\&D in Canadian Provinces,” Canadian Public Policy Vol. 31 No. 1, March, 29-44.

McKenzie, K.J. (2006), "Giving with One Hand, Taking Away with the Other: Canada's Tax System and Research and Development," C.D. Howe Institute Commentary, No. 240, October.

McKenzie, K.J. (2008), “Measuring Tax Incentives for R\&D," International Tax and Public Finance Vol.15, 563-581.

Mintz, Jack (1988), “An Empirical Estimate of Corporate Tax Refundability and Effective Tax Rates," The Quarterly Journal of Economics 103(1), 225-31.

OECD (2012), Economic Survey of Canada 2012.

Parsons, Mark and Nicholas Phillips (2007), "An Evaluation of the Federal Tax Credit for Scientific Research and Experimental Development," Department of Finance Working Paper 2007-08.

Public Works and Government Services Canada (2011), Innovation Canada: A Call to Action, Review of Federal Support to Research and Development - Expert Panel Report, at http://rdreview.ca/eic/site/033.nsf/vwapj/R-D_InnovationCanada_Final-eng.pdf/\$FILE/RD_InnovationCanada_Final-eng.pdf

\section{About the Author}

Kenneth J. McKenzie is a Professor in the Department of Economics and The School of Public Policy at the University of Calgary, where he has been since 1992. He received his B.Comm. from the University of Saskatchewan in 1982, his M.A. from the University of Calgary in 1985 and his Ph.D. from Queen's University in 1990. From 1984 to 1986 he was an economist in the Tax Policy Branch of the federal Department of Finance. His first academic appointment was at the University of Toronto in 1990. His principal area of research is public economics, with an emphasis on taxation and political economy. Professor McKenzie has received the Harry Johnson Prize for the best article in the Canadian Journal of Economics (1996, with Herb Emery). He is a two time winner of the Douglas Purvis Memorial Prize for a published work of excellence relating to Canadian public policy (1999, with Ron Kneebone; 2010, with Natalia Sershun). In 2000 he was the recipient of the Faculty of Social Sciences Distinguished Research Award at the University of Calgary. He was the EnCana Scholar at the C.D. Howe Institute, where he delivered the 2001 Benefactors Lecture, and has been a visiting fellow at research institutes in both Germany and Australia. He was the inaugural director in 2004 of the University of Calgary's Institute for Advanced Policy Research. Professor McKenzie has acted as an advisor to governments and institutions at the international, federal and provincial levels. He has been on the Panel of Experts for the International Monetary Fund and the World Bank and has provided analysis and advice on tax policy to several developing countries. He has sat on the Taxation and Finance Committee of the Alberta Economic Development Authority, was a member of the Alberta Business Tax Review Committee in 2000, an expert advisor to the Financial Review Commission in Alberta in 2002, and involved in research for the federal government's Technical Committee on Business Taxation in 1997. In 2007 he was a member of the Alberta Royalty Review Panel. Professor McKenzie has served on the Executive Council of the Canadian Economics Association, and on the editorial boards of the Canadian Journal of Economics and the Canadian Tax Journal and is past editor and associate editor of Canadian Public Policy. He served as Department Head in Economics from 2007-2010, and is currently Director of the Tax and Economic Growth Program in The School of Public Policy. 


\section{ABOUT THIS PUBLICATION}

The School of Public Policy Research Papers provide in-depth, evidence-based assessments and recommendations on a range of public policy issues. Research Papers are put through a stringent peer review process prior to being made available to academics, policy makers, the media and the public at large. Views expressed in The School of Public Policy Research Papers are the opinions of the author(s) and do not necessarily represent the view of The School of Public Policy.

\section{OUR MANDATE}

The University of Calgary is home to scholars in 16 faculties (offering more than 80 academic programs) and 36 Research Institutes and Centres including The School of Public Policy. Under the direction of Jack Mintz, Palmer Chair in Public Policy, and supported by more than 100 academics and researchers, the work of The School of Public Policy and its students contributes to a more meaningful and informed public debate on fiscal, social, energy, environmental and international issues to improve Canada's and Alberta's economic and social performance.

The School of Public Policy achieves its objectives through fostering ongoing partnerships with federal, provincial, state and municipal governments, industry associations, NGOs, and leading academic institutions internationally. Foreign Investment Advisory Committee of the World Bank, International Monetary Fund, Finance Canada, Department of Foreign Affairs and International Trade Canada, and Government of Alberta, are just some of the partners already engaged with the School's activities.

For those in government, The School of Public Policy helps to build capacity and assists in the training of public servants through degree and non-degree programs that are critical for an effective public service in Canada. For those outside of the public sector, its programs enhance the effectiveness of public policy, providing a better understanding of the objectives and limitations faced by governments in the application of legislation.

\section{DISTRIBUTION}

Our publications are available online at www.policyschool.ca.

\section{DISCLAIMER}

The opinions expressed in these publications are the authors' alone and therefore do not necessarily reflect the opinions of the supporters, staff, or boards of The School of Public Policy.

\section{COPYRIGHT}

Copyright (C) 2012 by The School of Public Policy.

All rights reserved. No part of this publication may be reproduced in any manner whatsoever without written permission except in the case of brief passages quoted in critical articles and reviews.

\section{ISSN}

1919-112x SPP Research Papers (Print)

1919-1138 SPP Research Papers (Online)

\section{DATE OF ISSUE}

July 2012

\section{MEDIA INQUIRIES AND INFORMATION}

For media inquiries, please contact Morten Paulsen at 403-453-0062.

Our web site, www.policyschool.ca, contains more information about The School's events, publications, and staff.

\section{DEVELOPMENT}

For information about contributing to The School of Public Policy, please contact Courtney Murphy by telephone at 403-210-7201 or by e-mail at cmurphy@ucalgary.ca.

\section{EDITOR}

Timothy Giannuzzi 


\section{RECENT PUBLICATIONS BY THE SCHOOL OF PUBLIC POLICY}

HOW YOU PAY DETERMINES WHAT YOU GET: ALTERNATIVE FINANCING OPTIONS AS A DETERMINANT OF PUBLICLY FUNDED HEALTH CARE IN CANADA

http:/ / policyschool.ucalgary.ca/ ?q=content/ how-you-pay-determines-what-you-get-alternative-financingoptions-determinant-publicly-funded-health-care-canada.pdf

Ronald Kneebone | June 2012

SUPPLY MANAGEMENT: PROBLEMS, POLITICS - AND POSSIBILITIES

http:/ / policyschool.ucalgary.ca/?q=content/ supply-management-problems-politics-and-possibilities.pdf Martha Hall Findlay | June 2012

POLICY OPTIONS FOR REDUCING DIETARY SODIUM INTAKE

http:/ / policyschool.ucalgary.ca/ ?q=content/ policy-options-reducing-dietary-sodium-intake.pdf Lindsay McLaren | June 2012

A WHITE PAPER* ON REFORMING CANADA'S TRANSPORTATION POLICIES FOR THE 21ST CENTURY http:/ / policyschool.ucalgary.ca/ ?q=content/ white-paper-reforming-canadas-transportation-policies-21scentury.pdf

Brian Flemming | June 2012

PREVENTING DOMESTIC VIOLENCE IN ALBERTA: A COST SAVINGS PERSPECIVE

http:/ / policyschool.ucalgary.ca/?q=content/ preventing-domestic-violence-alberta-cost-savingsperspective.pdf

Lana Wells, Casey Boodt and Herb Emery | June 2012

\section{NEGOTIATED SETTLEMENTS: LONG-TERM PROFITS AND COSTS}

http:// policyschool.ucalgary.ca/?q=content/ negotiated-settlements-long-term-profits-and-costs.pdf

G Kent Fellows | May 2012

REFORMING THE TAX MIX IN CANADA

http:/ / policyschool.ucalgary.ca/?q=content/ reforming-tax-mix-canada.pdf

Bev Dahlby | April 2012

TAXING CONSUMPTION OR INCOME: DU PAREIL AU MÊME?

http:// policyschool.ucalgary.ca/sites/default/files/research/cnossen-taxing-consumption.pdf Sijbren Cnossen | April 2012

THE GST/HST: CREATING AN INTEGRATED SALES TAX IN A FEDERAL COUNTRY http:// policyschool.ucalgary.ca/sites/default/files/research/bird-gst-hst.pdf Richard M. Bird | April 2012

A PROPOSAL TO CREATE A PAN-CANADIAN ENERGY INFORMATION ORGANIZATION (CEIO) http:/ / policyschool.ucalgary.ca/sites/default/files/research/m-moore-pancanadian.pdf Michal C. Moore | April 2012 